\title{
Analysis of the Effects of Direct Payment Subsidies for Environmentally-Friendly Agriculture on Income of Rice Farmers in Shiga, Japan
}

\author{
Danielle Katrina Santos ${ }^{1}$, Koji Shimada ${ }^{2}$
}

\begin{abstract}
This study will determine the economic effects of direct payment subsidies for EnvironmentallyFriendly Agriculture on income of rice farmers in Shiga Prefecture, Japan. It will specifically aim to: (1) analyze the effect of reduced chemical and fertilizer use on income and (2) come up with policy recommendation related to the implementation of direct payment subsidy. Environmentally-friendly agriculture has been promoted for over two decades as a response to the environmental challenges brought by climate change and biological loss. The Japanese government has endeavored to seek appropriate policies which reflect various environmentally-friendly farming practices such as organic farming and reduction of chemicals and fertilizers. The agro-environmental policy in Shiga is one of the earliest and most advanced in Japan. It aims to promote environmentally-friendly agriculture among farmers and to engage various stakeholders to protect the environment using the "Kodawari" slogan for Lake Biwa conservation and eco-farming. Rice as a staple food in Japan, this study will seek to address the notion that output and income of rice farmers receiving direct payment subsidies for agricultural inputs has not increased as evidenced by the study conducted by Kim (2014). In addition, chemical input is higher in Japan than most developed countries, this study will also aim to disprove the findings from the study conducted by Masuda (2016) that the current level of direct payment subsidy has only resulted to economic disadvantages in output for smaller environmental advantages. This study will contribute to the literature by analyzing an unexplored mandate of the direct payment scheme, particularly on the reduced use of chemicals and fertilizers, by explicitly determining the economic effects of the said program on income to determine how the gains from environmentally-friendly agriculture influence farmer's decision to produce.
\end{abstract}

Keywords: rice, direct payment subsidy, environmentally-friendly agriculture, income.

\section{Introduction}

Climate change affects food production, as agriculture is highly dependent on climate conditions such as temperature, sunlight, and precipitation. According to Stern as cited in Kunimitsu and Kudo (2015), a moderate level of warming of about $2^{\circ}$ to $3^{\circ} \mathrm{C}$ will be beneficial for countries located at higher latitudes. Situated at a relatively higher latitude, it is possible that Japan may benefit from future climate change (Kunimitsu \& Kudo, 2015) yet Japan is also a rare developed country located in the Asian Monsoon climate region, making the country vulnerable to the impacts of climate of change (Yamada, 2011). About 70\% of the Japanese farmers grow rice (Nikkei, 2017) making it necessary to advance the promotion of sustainable agriculture, particularly in paddy farming, for the protection of the environment and maintenance of biodiversity amidst intensive farming (Chen, Qiu, \& Nagata, 2013).

\footnotetext{
${ }^{1}$ Graduate School of Economics, Ritsumeikan University, 1-1-1 Noji-Higashi, Kusatsu, Shiga 525-8577, Japan

${ }^{2}$ Faculty of Economics, Ritsumeikan University, 1-1-1 Noji-Higashi, Kusatsu, Shiga 525-8577, Japan
} 
Environmentally-friendly agriculture has been promoted for over two decades as a response to the environmental challenges brought by climate change and biological loss (Chen, Qiu, \& Nagata, 2013). The Japanese government has endeavored to seek appropriate policies which reflect various environmentally-friendly farming practices such as organic farming and reduction of chemicals and fertilizers. As early as 1992, efforts to promote the nationwide adaptation of sustainable agriculture have been initiated. It was in the New Policy for Food, Agriculture, and Rural Areas (New Policy) issued by the Ministry of Agriculture, Forestry and Fisheries (MAFF) that environmental issues involving the agricultural sector were formally addressed for the first time in Japan. The importance of considering the environment in agricultural production was also first recognized in the New Policy for Food, Agriculture, and Rural Areas Basic Act in 1999 (New Basic Act). In order to provide countermeasures on the environmental impacts of agriculture, it was in the subsequent New Basic Act that environmentallyfriendly agriculture was written as a policy target, together with the creation of the Three Laws on Agro-Environment. In addition, the actual environmental payments at the national level appeared in the Measures to Conserve and Improve Land, Water, and Environment (MCILWE) in 2007 (Yamada, 2011), although establishment of the subsidy system for agro-environmental conservation and direct payments to eco-friendly farmers has not started until 2004 and 2011 respectively (Chen, Qiu, \& Nagata, 2013).

The agro-environmental policy in Shiga is one of the earliest and most advanced in Japan starting as early as 2004. It is also known for its uniqueness due to its policy objectives involving the conservation of Lake Biwa, occupying one-sixth of the prefecture's total land area. The prefectural government started the environmentallyfriendly certification policy and direct payments to farmers based on agreed stipulations on eco-farming. During this time, there was no mandate on direct payments for ecofriendly farmers from the central government. Under this policy scheme, Shiga Prefecture has implemented projects which aim to promote environmentally-friendly agriculture among farmers and to engage various stakeholders to protect the environment using the Kodawari slogan for Lake Biwa conservation and eco-farming (Yamada, 2011).

In 2007, MAFF instituted MCILWE which consist of two levels: the entry level and the advanced level (i.e. the level categorized as the agri-environmental scheme in this study). In the entry level, measures include coordination between farmers and nonfarmers in the maintenance of farm roads and agricultural canals while the advanced level include measures to reduce the use of agrichemicals and chemical fertilizers in a "collective manner" by as much as 50\%. The collective action for the reduced chemical use can be achieved by either one of the following:

1. At least $50 \%$ of the producers contribute to the reduction for each of the environmentally-friendly products; or,

2. At east $20 \%$ of the total farmland for all the products and at least $30 \%$ of the producers contribute to the reduction cumulatively for all the environmentally-friendly products.

This requirement is known as the "collective action prerequisite" and is key to the collaboration among farmers. Without changing the program certification, the prefectural government successfully transitioned to the national direct payment scheme. 
This was made possible through various initiatives of the prefectural government such as information sessions for farmers in various parts of the prefecture in 2006, prior to the commencement of the national program. The information sessions also involved the knowledge intermediation on the similarities and differences between the prefectural and national direct payment subsidy schemes. While the national scheme promoted collective actions, this practice was already a norm rather than a burden among farmers for collective use of agricultural inputs has already been in practice for rice cultivation (Nomura et al. 2013 as cited in Kishioka, Nishi, Hashimoto, \& Saito, 2017).

In spite of this initiative, adoption of sustainable farming, particularly organic farming, accounts for a small share of the cultivated land in Japan. According to the Japanese Ministry of Agriculture, Forestry, and Fisheries (2015), the share of organic in the domestic production was a mere $0.24 \%$ in 2015 . While the percentage of land devoted to organic agriculture has been gradually increasing, the share of organic farms remains low at $0.6 \%$ of the cultivated lands in Japan (Ministry of Agriculture, Forestry and Fisheries, 2017). Not to mention, the chemical input is higher in Japan compared to most developed countries in Europe.

The contribution of this paper is to focus on an approach to environmentallyfriendly agricultural practice which remains to be unexplored, to draw contrasting literatures about measuring the economic effect of direct payment subsidies and similar agro-environmental incentives at a different level of analysis, and show the implications for Shiga Prefecture, where Lake Biwa is located. Lake Biwa is known to suffer from poor water quality due to urbanization. Thus, this study was proposed to investigate the economic returns of the direct payment subsidy program for environmentally friendly agriculture among rice farmers in Shiga Prefecture, Japan .

\section{Literature Review}

Concerns about the environmental decline and sustainability of conventional agriculture have prompted the introduction of environmentally-friendly agricultural practices. The study conducted by Bravo-Ureta et al. (2005) analyzed the determinants of farm income among farmers who participated in in natural resource management projects in El Salvador and Honduras. The study estimated the farm income function using a three-equation system in which farm income is determined simultaneously by the farmer's production decisions which include soil conservation technologies and cropping system implemented on the farm. The study used a framework which would show the relationships among technology adoption, product diversification, and farm income. Surprisingly, the study also established that one of the factors affecting the household's decision-making process include the socioeconomic and agroecological environment apart from the conventional effects of prices, wages, and input, output, and financial markets. Results showed a significant increase in farm income with the adoption of soil conservation practices and a positive association between output diversification and farm income.

Another environmentally-friendly agricultural practice is the Integrated Pest Management (IPM). The study conducted by Dasgupta et al. (2004) used a survey data to compare the outcomes for farming with IPM and conventional techniques in 
Bangladesh, using input-use accounting, conventional production functions and frontier production estimation. Results showed that the productivity of IPM rice farming is not significantly different from the productivity of conventional farming in all three models of production. However, the study has emphasized that IPM reduced pesticide costs with no production loss, and appears to be more profitable than conventional rice farming, not to mention the substantial health and ecological benefits that comes with its adoption.

While organic farming has been well established in the West, it is still catching up in Asian countries. The study conducted by Lee et al. (2016) implemented a financial analysis to compare the annual costs and net returns of conventional, partially converted and environmentally friendly farming in Gangwon Province, South Korea. The study selected study areas which are within the watershed of Soyang Lake in Gangwon province, which is the largest reservoir and tributary located North of the Han River in South Korea. As a result of overpopulation, the residents in the downstream area of the watershed utilize the water resource overwhelmingly. Thus, water pollution in surrounding environmentally-sensitive areas, especially in the selected area, is seriously affected by intensive farming, and can seriously damage fresh drinking water use of the citizens. Using the survey data gathered through face-to-face interview with farmers, results showed the emergence of partially-converted farms (PCF) between conventional farms (CF) to environmentally-friendly farms (EFF). Despite the promotion of environmentally-friendly farming, there was a low acceptance of the said farming practice among farmers. Thus the study aimed to identify which farming technique is more profitable by financial analysis and to examine which factors affect the adoption of farming techniques in South Korea using multinomial logistic regression. Results showed that indeed the labor cost of EFF is higher than CF and PCF. On the other hand, with regards to the economic benefits, the net returns per farm and hectare of EFF were higher compared to $\mathrm{CF}$ and $\mathrm{PCF}$, when considering the total expenses, annual income and subsidies. Regardless, the results from the study conducted by Kim and Banfill (2011) showed that the subsidies are insufficient to serve as a proper incentive for income compensation to the farming household that implements environmentallyfriendly farming households. Although majority of the farmers expressed the opinion that "the program is necessary for continuous management of agriculture even though income is lower". This indicates that farmers accept the long term necessity of environmentally-friendly agriculture.

The inspiration for doing this study is the urgent need to conserve the Lake Biwa, the largest freshwater lake in Japan, for its valuable water resource use for the residents of Shiga Prefecture (Nakano, et al., 2008). Nakano et al. (2008) investigated the effects of natural environments and human activity on Lake Biwa, central Japan. They gathered river samples and analyzed the concentrations of the components $\left(\mathrm{Cl}, \mathrm{NO}_{3}\right.$, $\mathrm{SO}_{4}, \mathrm{Ca}, \mathrm{Mg}, \mathrm{Na}$, and $\mathrm{K}$ ) as well as the $\mathrm{pH}$ levels. Results showed that the Water quality of rivers greatly affected by human activity, specifically by industrial and agricultural sectors where the wastewater of the former is discharged directly into the rivers, whereas the wastewater of the latter seeps into the ground and then flows into the rivers.

Owing to the issue on the deteriorating water quality of Lake Biwa, greenhouse gas emissions from rice production has been the target of new research interest. Masuda 
(2016) examined the economic and environmental effects of the agri-environmental direct payment on the adoption of a measure to mitigate global warming in Japanese rice farms using a combined application of linear programming and life cycle assessment at the farm scale. He focused on the environmentally-friendly agricultural practice of prolonged midseason drainage technique. Results showed that under the current direct payment level, the prolonged midseason drainage technique did not improve the ecoefficiency of Japanese rice farms. In fact, the practice of this technique in environmentally-friendly rice farms caused large economic disadvantages in exchange for small environmental benefits.

\section{Theoretical Framework}

The theoretical framework of this study is grounded on welfare economics, in which direct payment rewards farmers for taking care of the environment. Farming activities both have a positive and negative effect from its non-tradable output. In any case, there are no markets that exist where third parties can either buy more of the positive externality or buy off some rights to produce less of the negative externality. For instance, conventional farming which employs high level of chemical inputs, higher yield is always associated with higher social costs due to more pollutants being discharged into the environment. However, the resulting external costs such as the water treatment of Lake Biwa, is not accounted for in the production costs of the farmers. On the other hand, environmentally-friendly agricultural practices improve the quality of the agroecosystem and thus generate a positive externality (Kim \& Banfill, 2011).

Direct payments can theoretically affect agricultural output through a technical efficiency channels. For instance, the study conducted by Fujie (2008), analyzed the behavior of farmers who participated in the environmentally-friendly agricultural product. Results showed that as farmers are more risk averse, the cropping ratio of environmentally-friendly agricultural products decline. However, the direct payment subsidies from environmentally-friendly agriculture increases the cropping ratio of environmentally-friendly agricultural products. In addition, an increase in the unit price of direct payment subsidy, increases the cropping ratio of environmentally-friendly agricultural products, which in turn has an impact on technical efficiency.

Direct payments also modify the wealth of farmers and thus creates the incentive to produce risk averse farmers For instance, Serra, Zilberman, and Gil (2007) as cited in Femenia, Gohin, and Carpentier (2010) considered the case where direct payments have a wealth effect on risk-averse producers leading them to increase their input use.

\section{Overview and Implementation Status of the Direct Payment Subsidy for Environmentally-Friendly Agriculture in Shiga Prefecture}

Farmers participating in the environmental agricultural direct payment system first make an environmentally-friendly agriculture agreement with the prefectural governor. The main contents of the agreement include:

i. reducing the use of chemical pesticides and fertilizers to less than $50 \%$ of the conventional practice; 
ii. proper use and management of compost and agricultural wastewater; and, iii. the agreement period is to be implemented for 5 years.

By signing the agreement and cultivating by the method specified in the production plan submitted to the prefecture, farmers can receive a certificate proving their implementation of environmentally-friendly agricultural cultivation on their products and receive the corresponding subsidies as shown in Table 1.

Table 1. Grant per unit price at the time of establishment of the prefecture independent system in 2004.

(JPY/10a)

\begin{tabular}{|l|l|l|}
\hline & Unit Price Indicator & $\begin{array}{l}\text { Less than } 50 \% \text { of the conventionally used synthetic } \\
\text { pesticide and chemical fertilizer }\end{array}$ \\
\hline \multirow{2}{*}{ Paddy Rice } & Less than $3 \mathrm{ha}$ & 5,000 \\
\cline { 2 - 3 } & Over $3 \mathrm{ha}$ & 2,500 \\
\hline
\end{tabular}

Source: Morino, 2016

The basis for the computation of the grant per unit price was based from the results of "Shiga Prefecture Environmentally-Friendly Agricultural Income and Expenditure Management", the amount of the difference in cultivation costs between conventional practice and the environmentally-friendly agricultural practice of $50 \%$ reduction in synthetic pesticides and chemical fertilizers will be used (Table 2). The total subsidy payment amount is JPY 5,000/10a (Morino M. , 2016). In 2019, a new payment amount was implemented, amounting to JPY 8,000/10a (Shiga Prefecture, 2019b).

Table 2. Calculation basis for paddy rice, 2004.

\begin{tabular}{|l|l|}
\hline Income & Environmentally-friendly Agriculture/Conventional Cultivation \\
\hline Yield & $95.8 \%$ \\
\hline Selling Price & $104.7 \%$ \\
\hline Gross Revenue & $100.3 \% \fallingdotseq 100 \%$ \\
\hline Production Costs (JPY/10a) \\
\hline Organic fertilizer cost & 5,090 \\
\hline Synthetic pesticide cost reduction & 3,204 \\
\hline Labor cost & 3,342 \\
\hline Total production costs & 5,228 \\
\hline
\end{tabular}

Source: Morino, 2016

According to Shiga Prefecture (2019b) the cultivation area of environmentally friendly agricultural products exceeded 14,000 ha in 10 years from the start of the certification system, but then it decreased temporarily and gradually increased to reach 15,609 ha in 2017 . Rice accounted for $45 \%$ of the total cultivated area. 

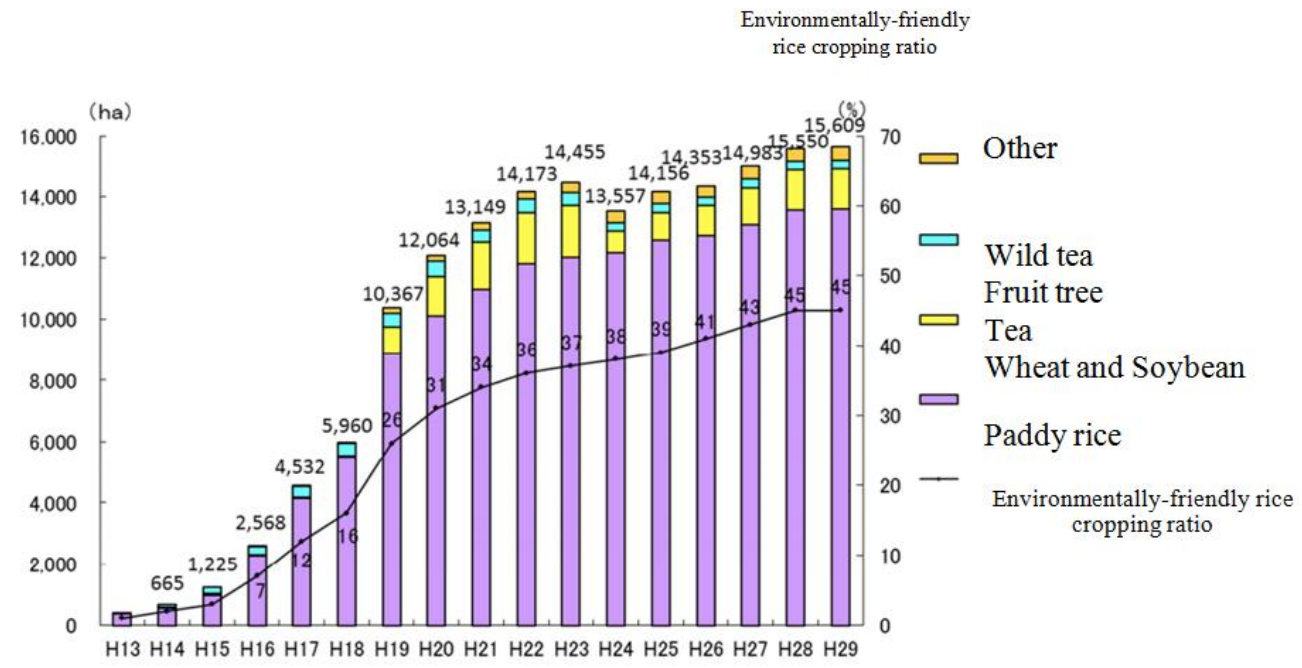

Source: Shiga Prefecture, 2019 b

Figure 1. Change in environment-friendly agricultural product cultivation area and environmentally-friendly rice cropping ratio, 2001-2017.

The planting of Mizukagami, which is produced entirely through environmentally-friendly agriculture, has been expanded to 2,575 ha (Figure 2). User demand in Kyoto-OsakaKobe metropolitan area has also been increasing.

In 2017 , the area covered by direct payment subsidy for 20\% (Figure 3). Shiga Prefecture has been ranked 1 st in terms of environmentally-friendly agriculture implementation in the whole country for 6 consecutive years.

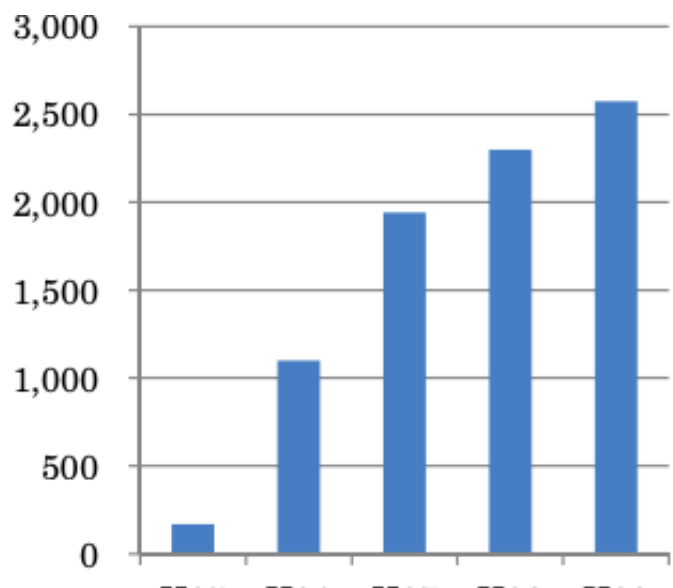

$\begin{array}{lllll}\mathrm{H} 25 & \mathrm{H} 26 & \mathrm{H} 27 & \mathrm{H} 28 & \mathrm{H} 29\end{array}$

Source: Shiga Prefecture, 2019 b

Figure 2. Change in the area (ha] cultivated for Mizukagami in Shiga prefecture, 2013-2017

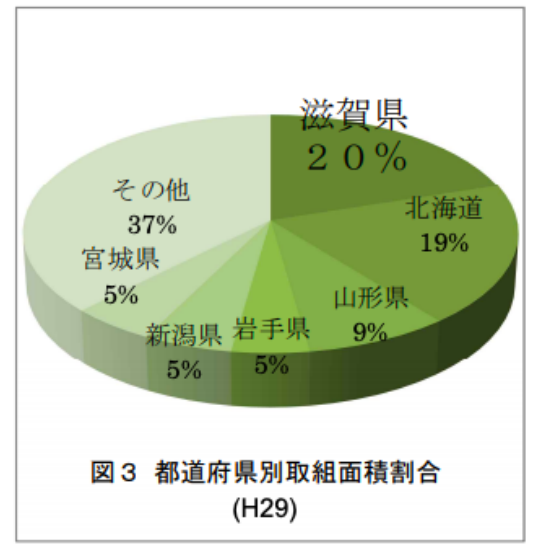

Source: Shiga Prefecture, $2019 b$

Figure 3. Area distribution of environmentally-friendly agriculture among prefecture in Japan 
The amount of synthetic pesticides used in the prefecture was also reduced by about $40 \%$ compared to 2000 , and the discharge of total nitrogen from agricultural lands to the Lake Biwa environment was reduced by 18.2\% in 2015 (Table 3) .

Table 3. Pollutant load inflow to Lake Biwa, 2017.

\begin{tabular}{|l|l|l|l|}
\hline & $\begin{array}{l}\text { Total N inflow load } \\
(\mathbf{k g} / \text { day })\end{array}$ & $\begin{array}{l}\text { Total P inflow load } \\
(\mathbf{k g} / \text { day })\end{array}$ & $\begin{array}{l}\text { COD inflow load } \\
(\mathbf{k g} / \text { day) }\end{array}$ \\
\hline 2000 fiscal year & 2,241 & 119 & 5,321 \\
\hline 2015 fiscal year & 1,834 & 101 & 4,611 \\
\hline Reduction Rate $(\%)$ & 18.2 & 15.1 & 13.3 \\
\hline
\end{tabular}

Source: Shiga Prefecture,

\section{Comparison between Shiga Prefecture's Environmentally-Friendly Agriculture Rice and Conventional Rice Cultivation}

Table 4 shows the comparison between the cost and returns of environmentallyfriendly and conventional rice. Results showed that the average planting area remains to be higher for conventional rice. Area cultivated for environmentally-friendly rice remains to be less than a hectare as compared to the conventional rice which is planted to 1.6 hectares. On the other hand, comparing the unit yield, selling price, labor cost, and production cost, the difference between environmentally-friendly and conventional rice is quite large. Conventional cultivation of rice would result in harvesting $1,034 \mathrm{~kg} / \mathrm{ha}$ more than the environmentally-friendly cultivation of rice through reduced use of synthetic pesticides and chemical fertilizers. In addition, the number of hours for labor has drastically increased to 124 man-hours on a per hectare basis as compared to the 21 man-hours per hectare required for conventional rice cultivation. With the additional cost on labor, the production cost has also increased by $93 \%$, amounting to JPY $1,183,860.00 /$ ha, not to mention the additional input cost due to usage of organic fertilizers to compensate for the $50 \%$ reduction in the use of chemical fertilizers and synthetic pesticides. On the contrary, the price difference due to the price premium of environmentally-friendly rice resulted to its higher selling price at JPY $12,983.00 / 60 \mathrm{~kg}$ as compared to the selling price of conventional rice amounting to JPY 11,011.00/60 kg .

Table 4. Average difference in planting area, yield, selling price, and management costs between environmentally-friendly and conventional rice, 2017.

\begin{tabular}{|l|l|l|}
\hline & Environmentally-Friendly Rice & Conventional Rice \\
\hline Average Planting Area (ha) & 0.128 & 1.6 \\
\hline Unit Yield (kg/ha) & 4,136 & 5,170 \\
\hline Selling Price (JPY/60 kg) & 12,983 & 11,011 \\
\hline Man-hour (hr) & 124 & 21 \\
\hline Production Costs (JPY/ha) & $1,183,386$ & $1,099,540$ \\
\hline
\end{tabular}

Source: Shiga Prefecture, Ministry of Agriculture, Fisheries, and Forestry, 2017. 
Partial budget analysis was used to quantify the differences in profitability of environmentally-friendly and conventional rice in Shiga Prefecture. The partial budget is a way of determining whether it is profitable to choose one farming method over the other by considering the difference in costs and benefits among the two farming methods.

Results of the partial budget analysis are shown in Table 5. With the information from the costs and returns analysis in Table 4, the additional costs were calculated by adding the input costs which included cost of organic fertilizer and labor. On the other hand, there was no reduced income since there were no returns that would not be received under the proposed change.

Environmentally-friendly farmers can receive a direct payment subsidy amounting to JPY 80,000.00 per hectare per year. On the other hand, reduced costs included the cost from using synthetic pesticides and chemical fertilizer amounting to JPY 32,040.00 per hectare per year.

The positive side of the change (additional income of JPY 80,000.00 plus reduced costs of JPY 32,040.00) amounted to JPY 112,040.00 per hectare per year. The negative side of the change (reduced income of JPY 0.00 plus additional costs of JPY 84,320.00) amounted to JPY 84,320.00 per hectare per year. When the positive aspects were compared with the negative aspects, notice that there was a positive difference of JPY 27,720.00 per hectare per year, suggesting that cultivation of rice through environmentally-friendly agriculture can generate a higher income for the farmers.

In order to account for the yield difference due to farming method, the theoretical yield reduction from environmentally-friendly rice cultivation was multiplied to the selling price of conventional rice. According to 胡柏 (2001), the decrease in yield from environmentally-friendly agriculture is about $12 \%$ or $620.4 \mathrm{~kg} / \mathrm{ha}$ (unit yield of conventional rice amounting to $5,170 \mathrm{~kg}$ multiplied by $12 \%$ ). Since the price of rice is JPY $11,011.00 / 60 \mathrm{~kg}$, the value of the yield difference due to farming method amounted to JPY 1,897.56/ kg (dividing the $620.4 \mathrm{~kg}$ by $60 \mathrm{~kg}$ since the selling price of rice is on a per $60 \mathrm{~kg}$ basis, and multiplying the resulting yield to the selling price of conventional rice which amounts to JPY 11,011.00/60kg or JPYy183.52/kg). Subtracting this value from the change in net income from Table 5, the change in net income due to the farming method amounted to JPY 25,822.40 per hectare per year. This value assumes that the effect of farming method on the increase in income due to an increase in output is removed and only the effect of subsidy is accounted for. 
Table 5. Partial budget analysis for shifting from conventional cultivation to environmentallyfriendly cultivation of rice per hectare, per year, Shiga Prefecture, 2017.

\begin{tabular}{|c|c|c|c|}
\hline Positive Effects & $\begin{array}{l}\text { Value } \\
\text { (JPY/ha/year) }\end{array}$ & Negative Effects & $\begin{array}{l}\text { Value } \\
\text { (JPY/ha/year) }\end{array}$ \\
\hline Additional income: & & Reduced income: & \\
\hline Direct payment subsidy & $80,000.00$ & None & 0 \\
\hline Total additional income: & $80,000.00$ & Total reduced income: & 0 \\
\hline $\begin{array}{l}\text { Table 5. Continued... } \\
\text { Reduced costs } \\
\text { Chemical fertilizer and } \\
\text { synthetic pesticide }\end{array}$ & $32,040.00$ & $\begin{array}{l}\text { Additional costs: } \\
\text { Organic fertilizer } \\
\text { Labor }\end{array}$ & $\begin{array}{l}50,900.00 \\
33,420.00\end{array}$ \\
\hline Total reduced costs: & $32,040.00$ & Total additional costs: & $84,320.00$ \\
\hline $\begin{array}{l}\text { Total additional income } \\
\text { and reduced r costs } \\
(\text { TAIRC) }\end{array}$ & $112,040.00$ & $\begin{array}{l}\text { Total reduced income } \\
\text { and additional costs } \\
\text { (TRIAC) }\end{array}$ & $84,320.00$ \\
\hline \multicolumn{2}{|c|}{$\begin{array}{l}\text { Change in income (TAIRC-TRIAC) } \\
\text { Less the value of theoretical yield difference due } \\
\text { to farming method }\end{array}$} & $\begin{array}{l}27,720.00 \\
1,897.60\end{array}$ & \\
\hline \multicolumn{2}{|l|}{ Change in income } & $25,822.40$ & \\
\hline
\end{tabular}

Source: Author's estimates, 2019.

\section{Summary and Conclusion}

The main objective of this study is to determine the economic effects of direct payment subsidies for Environmentally-Friendly Agriculture on income of rice farmers in Shiga Prefecture, Japan. The study had the following as its specific objects: (1) analyze the effect of reduced chemical and fertilizer use on income and (2) come up with policy recommendation related to the implementation of direct payment subsidy. The methods of analysis used included descriptive analysis for describing the implementation of the direct payment subsidy program, costs and returns analysis for comparing the differences in the farm performance of environmentally-friendly farmers and conventional farmers, and partial budgeting for analyzing the changes in costs and returns of environmentallyfriendly rice.

The study has concluded that environmentally-friendly agriculture was profitable. Results from the costs and returns analysis and partial budget analysis showed the difference in costs incurred as well as the returns received. Production costs of environmentally-friendly farmers may have been higher than that of conventional farmers but the difference was offset by the direct payment subsidy received. Income obtained from environmentally-friendly rice cultivation remained to be positive, thus it is sufficient to say that income obtained from environmentally-friendly agriculture was 
higher than the income from conventional farming, isolating the effect of direct payment subsidy rather than the effect of yield difference due to farming method. In addition, the environmentally-friendly farmers have also received a price premium for their rice resulting to its higher selling price.

Based on these findings, it may be concluded that the substitution of environmentally-friendly agriculture for conventional rice farming had resulted to an increased farm income due to the direct payment subsidy received.

\section{Recommendation}

Since the estimates indicated a higher income, it only signifies that the benefits from environmentally-friendly agriculture were higher than conventional farming. Therefore, environmentally-friendly agriculture is recommended for rice production. Based from the findings of the study, the government should aim to popularize environmentally-friendly agriculture to increase the production of environmentallyfriendly products through localized agricultural administration that would dispel the farmer's failure to realize economies of scale due to low income received and high production costs due to high labor requirement and high organic fertilizer cost. Promotion of environmentally-friendly agricultural practice can significantly reduce the external costs such as pollution load to the Lake Biwa ecosystem and increase farm income as well. Direct intervention such as introduction of various technologies that would save costs on applying organic fertilizers to supplement the fertility of the soil as an alternative to chemical fertilizers and synthetic pesticides, and incentives such as direct payment subsidies should be used to induce farmers to adopt environmentally-friendly agriculture.

\section{References}

Bravo-Ureta, B. E., Solis, D., Cocchi, H., \& Quiroga, R. E. (2006). The impact of soil conservation and output diversification on farm income in Central American hillside farming. Agricultural Economics 35 (2006), 267-276.

Chen, B., Qiu, Z., \& Nagata, A. (2013). Review of Sustainable Agriculture: Promotion, Its Challenges and Opportunities in Japan. Journal of Resources and Ecology, 231-241.

Dasgupta, S., Meisner, C., \& Wheeler, D. (2007). Is Environmentally-Friendly Agriculture Less Profitable for Farmers? Evidence on Integrated Pest Management in Bangladesh. Review of Agricultural Economics 29 (1), 103-118.

Femenia , F., Gohin , A., \& Carpentie, A. (2010). The Decoupling of Farm Programs: Revisiting the Wealth Effect. American Journal of Agricultural Economics Volume 92, Issue 3, 836-848.

Fujie, T. (2008). Economic Analysis of Agricultural Environmental Policy-Focusing on Environmental Agriculture Direct Payment System in Shiga Prefecture. 『彦根論叢』, No. 370, 65-85.

Kim, C. G., \& Banfill, J. (2011). A Policy Evaluation of Environmental-Friendly Direct Payment Programme in Korea. OECD, Paris, France. [2014-3-20]. Retrieved from http://www.oecd.org/tad/sustainable-agriculture/48170214.pdf

Kunimitsu, Y., \& Kudo, R. (2015). Fluctuations in Rice Productivity Caused by Long and Heavy Rain Under Climate Change in Japan: Evidence from Panel Data Regression Analysis. Japan Agricultural Research Quarterly,,159-172.

Land of Plenty . (2018, Jun 25). Retrieved from Oishi: https://www.oishii.sg/article/4468/ 
Lee, S., Nguyen, T. T., Poppenborg, P., Shin, H.-J., \& Koellner, T. (2016). Conventional, Partially Converted and Environmentally Friendly Farming in South Korea: Profitability and Factors Affecting Farmers' Choice. Sustainability 2016, 8, 704;, 2-18.

Li, X. N., \& Li, R. (2013). The Effect of Grain Subsidies on the Production and Farmers' Income in China. 2013 International Conference on Management Science \& Engineering (20th), (pp. 2162-2167). China.

Masuda, K. (2016). Optimization Model for Mitigating Global Warming at the Farm Scale: An Application to Japanese Rice Farms. Sustainability, MDPI, Open Access Journal, vol. 8(7), 1-17.

Murathi Kiratu, N. (2014). An Assessment of the Impact of Kilimo Plus Subsidy Program on Smallholder Farmers' Food Security and Income in Nakuru North District, Kenya, Research Theses, 43470, Collaborative Masters Program in Agricultural and Applied Economics.

Morino, K. (n.d.). Wastewater Management in the Lake Biwa Basin. Retrieved from http://www.nilim.go.jp/lab/bcg/siryou/tnn/tnn0264pdf/ks0264023.pdf

Nakano, T., Tayasu, I., Yamada, Y., Hosono, T., Igeta, A., Hyodo, F., . . Y Yachi, S. (2008). Effect of agriculture on water quality of Lake Biwa tributaries, Japan. Science of Total Environment 389 (2008), 132-148.

Nikkei. (2017). Japan to Stop Coddling its Rice Farmers.

Ministry of Agriculture, Forestry and Fisheries. (2017a). Agricultural Production Costs Statistics. Retrieved from http://www.maff.go.jp/j/tokei/kouhyou/noukei/seisanhi_nousan/

Ministry of Agriculture, Forestry, and Fisheries. (2017b). Amount of Rice Harvest in 2017 (Kinki). Retrieved from http://www.maff.go.jp/kinki/press/toukei/seiryu/171205.html

Ministry of Agriculture, Forestry, and Fisheries . (2017c). Amount of Rice Harvested in 2017 (Shiga Prefecture). Shiga, Japan.

Ministry of Agriculture, Forestry, and Fisheries. (2017d). Current Status of Rice Cultivation and Its Problems. Japan.

Ministry of Agriculture, Forestry and Fisheries. (2017e, August). Promotion of Organic Agriculture. Japan.

Ministry of Agriculture, Forestry, and Fisheries. (2017f). Relative Transaction Price and Quantity of Rice $\begin{array}{lllll}\text { Produced in } 2017 & \text { Retrieved from }\end{array}$ http://www.maff.go.jp/j/press/seisaku_tokatu/kikaku/171013.html

Ohmi Rice Promotion Association. (2019). Mizukagami Cultivation Manual. Shiga, Japan.

Shiga Prefecture . (2013). Cultivation Expansion and Stabilization of Taste and Quality of Rice Variety "Mizukagami". Shiga, Japan.

Shiga Prefecture. (2018). Life with Lake Biwaびわ湖と暮らし. Retrieved from https://www.pref.shiga.lg.jp/file/attachment/4037776.pdf

Shiga Prefecture. (2019a). Environmentally-friendly Agriculture Direct Payment Grant (support for cultivation of environmentally-friendly agricultural products). Retrieved from 滋賀県: http://www.pref.shiga.lg.jp/g/kodawari/files/h31kanchokupanfu.pdf

Shiga Prefecture. (2019b). Shiga Prefecture Environmentally Friendly Agriculture Promotion Basic Plan Original Proposal (Draft)滋賀県環境こだわり農業 推進基本計画原案（案）。 Retrieved from https://www.pref.shiga.lg.jp/file/attachment/4018774.pdf

Shiga Prefecture. (2019c). Shiga Prefecture Basic Plan 2019. Shiga, Japan.

Yamada, N. (2011). Agro-environmental Policies in Japan and Attendant Challenges: Countermeasures for the Agricultural Sector. In J. Bi , K. Otsuka, J. Ge, \& S. Wang (Eds.), Stakeholder Involvement in Water Environment Conservation in China and Japan: Building Effective Governance in the Tai Lake Basin. IDE Joint Research Program Series No.155.

胡柏. (2001). Profit Formation Ability and Formation Condition Analysis of Environmentally-Friendly Rice Cultivation: The Case of Kyushu Region. 農業経済研究第 73 巻，第 1号.,1-15. 